\title{
Protestant-Dominant
}

\section{Between Representation and Subjectivity}

\section{Interreligious Dialogue in Denmark}

\author{
Lise Paulsen Galal \\ Associate Professor, Department of Communication and Arts, Roskilde \\ University, Roskilde, Denmark \\ galal@ruc.dk
}

\begin{abstract}
Religious actors and bodies from within the Evangelical Lutheran Church in Denmark have increasingly adopted interreligious dialogue as an instrument dealing with changes of the religious landscape due to immigration, religious radicalisation and secularisation. Without any formal body representing the entire church, interreligious dialogue emerges from a variety of initiatives. Whereas these can be divided between religious leaders' versus people-to-people's dialogue, I will argue that both models are characterised by being decentralised and culturalised while dealing with the simultaneous subjectivity and representation of the individual believer.
\end{abstract}

\section{Keywords}

representation - subjectivity-The Church of Denmark-N.F.S. Grundtvig - peoplehood

In recent years, there have been an increasing number of incidents nationally and internationally that have changed the conditions for the 
interreligious encounter. Terrorist attacks, increasing flows of refugees, the advance of new political parties on the far right, etc. ${ }^{1}$

The encounter between religions always implies an encounter between individual human beings. Human beings always carry with them their faith and culture, their language, their gender identity and their personal history. Religious belief does not exist independently of those who believe. Therefore, there is great diversity within all religious traditions. ${ }^{2}$

The two quotes, which are from the website of The Committee for Church and Encounter with other Religions (Folkekirke og Religionsmøde), illustrate the two levels of encounters that interreligious initiatives in Denmark characteristically relate to when arguing for setting up interreligious encounters. There is a societal level defined by particular problems and there is the personal encounter between individuals of different religious backgrounds. The first quote is from the committee's latest published plan of action, and the second quote is from its guideline for interreligious dialogue. Symptomatically the action plan does not explain how terrorist attacks relate to interreligious dialogue, which suggests that the challenge appears as self-evident. The second quote is about how to enter interreligious encounter with an awareness of varieties in individual religious belief.

On the one hand, the two quotes together mirror the general approach of interreligious dialogue, which stipulates that you address challenges at the macro-level by scaling them down to face-to-face encounters at the microlevel. ${ }^{3}$ For this face-to-face encounter, there are guidelines and recommendations with the ultimate hope that the change of people taking part in interreligious dialogue may subsequently be 'scaled up' to collective or societal relations. ${ }^{4}$ In other words, the quotes reflect a particular idea of how to create transformation. Whereas this idea could be discussed in terms of 'theoretical individualism' with roots in the contact hypothesis often referred to in intercultural settings, ${ }^{5}$ we may, on the other hand, also ask how the two quotes reflect particular Danish ideas of working with interreligious dialogue. Not only

1 Plan of action for Folkekirke og Religionsmøde. All translations from Danish into English are by the author.

2 Vejledning i religionsmøde.

3 See for instance: Mayblin/Valentine/Andersson, In the Contact Zone; Agrawal/Barratt, Does Proximity Matter; Fortier, Proximity by Design?; Valentine, Living with Difference; Wilson, On Geography and Encounter; Wolf, Intercultural Identity and Inter-Religious Dialogue.

4 Matejskova/Leitner, Urban Encounters with Difference, p. 719.

5 Connolly, What Now for the Contact Hypothesis?, p. 170. 
are interreligious dialogue initiatives responsive to particular changes within the Danish society, they also draw on understandings of Danish peoplehood and the role of Christianity herein. In direct continuation of the quote on encounters between individuals follows a paragraph that presents a generalised Christian 'we': "Therefore Christians always in some respect represent the church in the encounter with others." of the Evangelical Lutheran Churches in Denmark, the committee's emphasis on Christianity and the church is not surprising. However, the generalised Christian 'we' that runs through the text not only appears paradoxically when in the paragraph before the importance of acknowledging variations within religious traditions is emphasised. It also reflects a particular Danish Christian 'we' that is historically rooted in Protestantism and Folkekirken (literally meaning the People's Church), which is the common name for the Evangelical Lutheran Church in Denmark, which I will address in the following as the Church of Denmark. There is no doubt that interreligious dialogue in Denmark is influenced by several streams of ideas, nationally and internationally. In this paper, the focus is on the particularities of the Danish context and how specific ideas about people, church, and secularism influence interreligious dialogue. I will argue that the close connection between the Church of Denmark and the Danish People is majoritised as the cultural national norm, which together with the decentralised structure of church activities shape how interreligious dialogue is understood and organised.

The paper proceeds with a short note on state of the art and conceptual framing. Next follows an introduction to the historical background of religious freedom, diversity and their governance in Denmark, emphasising peoplehood and the encounter with Muslim immigrants as two socio-cultural aspects of key importance to understand the organisation of interreligious dialogue in Denmark today. Their impact is examined through the identification and discussion of how representation and subjectivity are produced within two versions of interreligious dialogue: the leaders' and people-to-people's dialogue.

\section{Interreligious Dialogue - Approaches and Concepts}

Whereas Danish studies of interreligious dialogue are relatively limited, it is, though, possible to identify three strands of research. The first strand of research has been dominated by theologians who respond to the new religious diversity due to immigration but also to new approaches to mission work. They

6 Vejledning i religionsmøde. 
are often those who at the same time are initiators, organisers or active supporters of interreligious dialogue. ${ }^{7}$ Typically, these studies are characterised by a mixture of defining the theological foundation for interreligious dialogue and describing specific initiatives. This is what Anne Hege Grung names the 'inside' of the interreligious dialogue, while the 'outside' is "where the religious, political and social implications and effects of the dialogues may be explored." second strand belongs to the 'outside' by focusing on church bodies, structural and organisational aspects. Accordingly, and placed within studies of religious tradition, a comparative study of religious complexity in the Nordic countries describes the development of general church and interfaith bodies. However, the study's examination of Denmark is limited, because - as Inger Furseth et.al. write - Denmark has a weaker interfaith infrastructure. ${ }^{9}$ Another comparative study shows how Danish interfaith activities are indeed influenced by its fragmented structure, thereby continuing the focus on the organising of interfaith dialogue work..$^{10} \mathrm{~A}$ third, but still novel strand of research also belongs to the 'outside' but adopts a cross-disciplinary approach asking how the (theological) ideas behind and the (religious) organising of interreligious dialogue produce a particular kind of social practice exploring the outcome - or, in other words, the social and intercultural implications of interreligious dialogue. ${ }^{11}$

Placing the present work within the third strand of research, I ask how the Danish interreligious field is influenced by particular ideas of peoplehood and (secular) Christianity and how these are embedded in the social practices of interreligious dialogue. To conceptualise the encounter taking place, I adopt Mary Louise Pratt's concept of the contact zone, which she defines as:

Baig, Rasmussen/Iversen, Human First - To Be Witnesses to Each Other's Life; Christoffersen, Hoxbroe/Vinding, From a Common Word to Committed Partnership; Hansen, ChristianMuslim Relations in Egypt; Jørgensen, Det Nye Areopagos; Mogensen, Mellem Mission Og Dialog; Mogensen/Christensen, Rapport Fra: Tcenketank Vedr; Rasmussen, Bridges Instead of Walls.

8 Grung, Interreligious Dialogue, p. 25.

$9 \quad$ Furseth et al., Faith and Worldview Communities and Their Leaders, p. 276.

$10 \mathrm{Galal} /$ Liebmann/Nordin, Routes and Relations in Scandinavian Interfaith Forums.

11 Galal, Dialogens Arrangement; Galal, Interfaith Dialogue - a Quest for Authenticity; Galal, Making Space for Faith; Helqvist, Muslimske Interesseorganisationers; Petersen, Intercultural Encounters in the Danish Church. Laura Bjørg Serup Petersen is working at a PhD project at Aarhus University with the title 'Intercultural Ecclesiology - a practical theological study of lived ecclesiology in intercultural encounters in the Evangelical Lutheran Church of Denmark.' As the title indicates, this is primarily placed within the theological tradition but she appears to include more critical and cross-disciplinary approaches as well. 
[...] social spaces where cultures meet, clash, and grapple with each other, often in contexts of highly asymmetrical relations of power, such as colonialism, slavery, or their aftermaths as they are lived out in many parts of the world today. ${ }^{12}$

With this definition, Pratt points at the significance of asymmetrical power relations within the encounter at the same time as the contact zone is considered messy and potentially chaotic. Crucial here is that imaginaries of order, and hence chaos, are historically constituted and seen from the perspective of the dominant positions. ${ }^{13}$ Translated into the Danish interreligious context, the Church of Denmark - from its position as the dominant organiser of religion in Denmark - finds the arrival of other religions potentially threatening to the order that the church upholds for what it considers being the common good. Interreligious dialogue initiatives become a means to counter such potential chaos. In other words, my approach to interreligious dialogue is to study dialogue activities as purposeful interventions into the potential messiness or chaos of the contact zone. ${ }^{14}$ The intentionality of the interventions makes them into scripted social situations, where roles and subjectivities are distributed according to space, time and power relations. Rather than identifying ideal types of dialogue, e.g. peace prayers, discussion groups, neighbourhood festivals etc., ${ }^{15}$ my aim is to examine how particular kinds of interreligious dialogue offer particular roles - and thus subjectivities - to the participants and how these are embedded in the history of organising religious diversity in Denmark. I am especially interested in exploring organisers' apparent paradoxical and ambivalent expectation that participants simultaneously represent 'a particular religion' while talking only 'on behalf of themselves'. Whereas this ambivalence is ingrained in the set-up of interreligious dialogue by inviting participants due to their religious identity while scaling down the encounter to encounters between individuals, the ambivalence is also embedded in the history of Protestantism and secularism in a Danish context.

To examine the entanglement between majority traditions and interreligious dialogue, I will in the following explore how two ideal typical dialogue

\footnotetext{
12 Pratt, Arts of the Contact Zone, p. 34.

13 Galal/Hvenegård-Lassen, Organised Cultural Encounters. Global Diversities.

14 Christiansen/Galal/Hvenegård-Lassen, Organised Cultural Encounters. Interculturality and Transformative Practices.

15 Dick/Nagel, Local Interfaith Networks in Urban Integration Politics.
} 
forms (leaders' and people-to-people's dialogue respectively) ${ }^{16}$ are approached and managed by majority institutions and interreligious dialogue initiatives. The findings are based on data collected in the research project Interfaith dialogue for change which is a sub-project of the collective project The organised cultural encounters that explored six different kinds of organised cultural encounters. ${ }^{17}$ Whereas interreligious dialogue may take many forms, I only include initiatives that are explicitly and purposefully organised in order to intervene in problems that are seen as caused by or, more weakly in terms of determination, related to religious difference. ${ }^{18}$ The data material consists of participant observation of 14 different kinds of interfaith dialogue activities, including a weekend course, a church festival, half-day meetings, and evening events with organisers from different organisations and NGO s. Except for a dialogue conference in Lebanon, the fieldwork took place in Denmark in the years 2015-2018. In addition, 15 semi-structured qualitative interviews with organisers were conducted, together with more than 40 informal conversations with organisers and participants during fieldwork.

To understand the interreligious dialogue field in a Danish context, two aspects appear to be essential: the decentralisation of the Church of Denmark and the idea of peoplehood. Both aspects matured around the time when Denmark went from absolute monarchy to democracy. In 1849, Denmark adopted a new constitution that stipulated freedom of religion and protection against discrimination due to creed. With the constitution, the Church of Denmark went from being the King's church to becoming the people's church, replacing the political system of the King as the absolutist ruler since 1660 with - the beginning of - a people's rule. ${ }^{19}$ The Church of Denmark kept its special status as eligible for support from the state, while the close association between monarchy and church was safeguarded with the constitutional demand that the King should be a member of the Evangelical Lutheran Church. ${ }^{20}$ At the time, a

\footnotetext{
16 Some would name these top-down and bottom-up forms of dialogue, but as will appear this terminology would be misleading because of the decentralised structure of the Church of Denmark.

17 The project 'The Organised Cultural Encounter' was funded by the Danish Council for Independent Research with funding-ID: DFF-1319-0oo93.

18 Galal/Hvenegård-Lassen, Organised Cultural Encounters. Global Diversities.

19 Nielsen, Appealing to the State Church Identity.

20 Nielsen/Kühle, Religion and State in Denmark.
} 
blend of liberal ideas informed by Enlightenment and ideas from romanticism, especially a romantic nationalism - or peoplehood - was promoted by, among others, the Danish theologian and politician N.F.S. Grundtvig (1783-1872). Grundtvig later became a symbol of a particular interpretation of the intersection between Danish nationality and Christianity as embedded in the people and peoplehood - or folk - referring to the cohesiveness of an ethnic group or nation due to its own specific national soul. ${ }^{21}$ Connecting romantic notions of the people, the church and the individual was seen as a protection against abrupt social changes. ${ }^{22}$

The idea of peoplehood therefore also influenced the governance of the church. Whereas the state was given the legislative power over the Church of Denmark, the local parochial church councils were granted - and still have a high degree of independence regarding internal affairs, for instance in hiring pastors and deciding on issues related to rites and worship. ${ }^{23}$ According to Dabelsteen, the parliament and the church had a shared interest in letting the church govern its own affairs as it otherwise "could lead to religious contestation and denaturalise the image of the Folkekirke as a site of shared national belonging."24 Furthermore, the lack of an independent, national representation, for instance a church council or synod, has strengthened the decentralised power of the Church of Denmark.

The Church of Denmark is still formally connected to the state. It organises the majority of Danes religiously with $74.3 \%$ of the population being members as of 1 January $2020,{ }^{25}$ compared to $89.3 \%$ in $1990 .{ }^{26}$ The decrease is due to a combination of people leaving the church, not being baptised as children and therefore not becoming members, and a growing number of residents with other religious belongings, primarily due to immigration. As the number of inhabitants in Denmark has increased by around 600,00o since 1990, the change mainly applied to the relative but not the total numbers of church members, which were $4,584,450$ in 1990 compared to $4,327,018$ as of 1 January $2020 .{ }^{27}$

Regardless of the high numbers of Danish Church members, Norris and Inglehart argue that Denmark is one of the most secularised nations in the

\footnotetext{
21 Korsgaard, Grundtvigs Bidrag Til Opbygning.

22 Dabelsteen, Unity Through Separation, pp. 142 et seq.

23 Dabelsteen, Same Rights for Everybody?, p. 42.

24 Dabelsteen, Same Rights for Everybody?, p. 42.

25 Within the last ten years, attempts to separate the church from the state have been fruitless.

26 See Kirkeministeriet. Folkekirkens medlemstal.

27 See Kirkeministeriet. Folkekirkens medlemstal.
} 
world when measured on religious practice and personal belief. ${ }^{28}$ Among others, two aspects - of relevance for the interreligious field in Denmark may explain this apparent contradiction. Firstly, the Church of Denmark embodies what Grace Davie has conceptualised as the vicarious role of the church addressing the ambiguous role of established churches in Europe which - regardless of their hastily decreasing influence on the everyday lives of Europeans - are assigned a legitimate role as housing an active minority that performs religion on behalf of an approving majority of the population. ${ }^{29}$ According to Davie, religion can work vicariously in various ways such as the performance of rituals, embodying social and moral codes on behalf of others, or offering a space for public debate on controversial topics. ${ }^{30}$ When enacting interreligious dialogue, the Church of Denmark therefore may work vicariously on behalf of the Danish protestant majority. ${ }^{31}$ Secondly, the historical convergence of peoplehood and Christianity has been a way of culturalising (and secularising) religion in Denmark, producing a cultural Protestantism, which is endorsed by a much wider circle than the church. ${ }^{32}$ This is also reflected in interreligious dialogue work, as I will get back to in the following.

\subsection{Religious Diversity and Its Governance}

While the Church of Denmark has been the body that organised the large majority of the Danish population religiously, Catholics, Jews and other Christians (for instance the Huguenots) have historically been tolerated religious minorities. Besides the right of religious freedom, the constitution of 1849 promised that a law would be drawn up to regulate religious communities outside the Church of Denmark. More than a 150 years later in 2018, this law became reality offering religious communities outside the Church of Denmark the possibility of obtaining authorisation. ${ }^{33}$ Until then, the regulative handling of religious communities outside the Church of Denmark was regulated under private law on associations, charities or private institutions. ${ }^{34}$

28 Norris/Inglehart, Sacred and Secular, p. 84.

29 Davie, Religion in Europe in the 21 St Century, p. 24.

30 Davie, Religion in Europe in the 21 St Century, pp. 25 et seq.

31 Galal/Liebmann/Nordin, Routes and Relations in Scandinavian Interfaith Forums.

32 Buchardt, Cultural Protestantism and Nordic Religious Education; Joppke, Culturalizing Religion in Western Europe.

33 Law on religious communities outside Folkekirken (Lov om trossamfund uden for folkekirken), Law no 1533, 19/12/2017, available from https://www.retsinformation.dk/ Forms/ro710.aspx?id=196402.

34 Vinding/Christoffersen, Danish Regulation of Religion, State of Affairs and Qualitative Reflections, p. 12. 
In Denmark, no official registration of individual religious belonging exists except for members of the Church of Denmark due to their payment of church tax to the State. Knowledge of membership of other religious communities only exists if the organisations themselves have somehow publicly informed about the number of members. ${ }^{35}$ Considering that people may also have a religious belonging without formally being associated with a specific community, the numbers are rather bleak. Generally, the way of counting religious belonging is therefore to calculate followers based on country of origin. Obviously, these calculations include people who are not necessarily members of a specific faith community, or do not even believe, but have a background in for instance a Muslim or Hindu country.

Based on such calculations, about 256 , ooo in total numbers and $4.4 \%$ of the Danish population are Muslims (as of 1 January 2020). They constitute the largest religious minority group in Denmark. ${ }^{36}$ Most are immigrants or descendants of immigrants. The largest groups have origins in Turkey, Syria, Iraq, Lebanon, Pakistan, Somalia, Afghanistan, Bosnia, Iran and Morocco. ${ }^{37}$ There are 47,673 members of the Catholic Church in Denmark (as of 1 October 2017). ${ }^{38}$ Jews have lived in Denmark since the 16oos and constitute today about 7,000 people, most of whom live in Copenhagen. Only about half of the Danish Jews are members of a Jewish congregation. ${ }^{39}$ Other groups, like Hindus (19-20,000 in 2018, mainly with a background in Sri Lanka and India), ${ }^{40}$ Buddhists (33,000 in 2018, of which 90\% have an immigrant background), ${ }^{41}$ and members of Orthodox Churches are not very visible in public.

In contrast to other European countries' embracement of interreligious dialogue as an official policy on different levels of society, ${ }^{42}$ the Danish state does not perceive it as its role to initiate or enter into interreligious dialogue. ${ }^{43}$

According to the new 'Law on religious communities outside Folkekirken', religious communities that apply for authorisation have to state number of members, but not to provide member lists. Furthermore the numbers are until now not made public, and only include recognised faith groups.

36 Kristensen, Hvor Mange Muslimer Er Der i Danmark.

37 Jacobsen, Denmark.

38 Den katolske Kirke i Danmark. Statistik.

39 https://joediskinfo.dk/artikler/danske-joeder.

$40 \quad$ Fibiger, Hvor mange hinduer.

41 Borup, Hvor mange buddhister.

42 Duemmler/Nagel, Governing Religious Diversity; Griera, Public Policies; Griera/Nagel, Interreligious Relations and Governance of Religion in Europe; Liebmann, Interfaith Dialogue in Christian Norway; Giordan/Lynch, Interreligious Dialogue: From Religion to Geopolitics.

43 Galal/Liebmann/Nordin, Routes and Relations in Scandinavian Interfaith Forums. 
Contrary to Sweden and Norway and in line with the lack of church council or synod, Denmark does not have any national interfaith body. ${ }^{44}$ Likewise, other faith communities have, despite attempts of constructing national councils, for instance the Muslim Council of Denmark, a limited impact on for instance public debate about religious diversity. Without well-defined - state or church - dialogue bodies and partners, the dialogue has become decentralised leading to many non-coordinated initiatives. As far as these address current issues of general concern of the Danish society, the State is willingly supporting such initiatives financially. However, funding depends on what kinds of problematics the activities are supposed to counteract (e.g. lack of integration, terrorism), rather than by the interreligious dialogue itself. Consequently, funding may alternate between the Ministry of Church, Ministry of Integration, or Ministry of Foreign Affairs. As such, the Danish State embraces neoliberal policies that increasingly appeal to civil society, including religious associations, to shoulder some of the welfare tasks in the Danish society. ${ }^{45}$ Based on its historically strong and non-hierarchical infrastructure, ${ }^{46}$ the Church of Denmark provides a solid basis for supporting interreligious activities due to its flexibility in decision-making, its tradition for including different theological positions, its willingness to pragmatic and case-based work, while being a source for funding or fundraising.

Like in other European countries, particularly Islam has received attention as a new minority religion. Allegedly a primary threat against secular (and Danish) values in combination with cases of Islamic radicalisation and terrorism has led to an increasingly anti-Muslim public discourse and securitisation of Islam. ${ }^{47}$ Not surprisingly, the interreligious dialogue with Muslims has therefore been a priority that reflects how they have been problematized over time. The example of the Islamic-Christian Study Centre illustrates the development. The centre was the first interreligious initiative addressing Muslims in Denmark, today known as the Centre for Co-Existence. Established by a group of Christians and Muslims in collaboration in 1996, it wanted to create a sort of free space, where Muslims and Christians could meet and feel safe, talk and do projects together. ${ }^{48}$ The key person was Lissi Rasmussen, a pastor within the Church of Denmark, who is still the director and chairman of the board, which consists of equally as many Muslims as Christians. In the beginning,

\footnotetext{
44 Galal/Liebmann/Nordin, Routes and Relations in Scandinavian Interfaith Forums.

45 Martikainen, Multilevel and Pluricentric Network Governance of Religion.

46 Nielsen, Appealing to the State Church Identity.

47 Andreassen/Ahmed-Andresen, I Can Never Be Normal; Jacobsen, Denmark; Hansen/ Herbert, Life in the Spotlight.

48 https://www.facebook.com/groups/studiecenter/about/.
} 
focus was on micro-level dialogue in study groups consisting of Christians and Muslims that met in smaller groups to talk about and listen to each other's belief and faith experiences. Another priority was education and information about Islam and Muslim-Christian relations. Today, the centre mainly works with social projects. Whereas this approach is in accordance with the chairman's own vision of diapraxis as the way forward for interreligious relations, ${ }^{49}$ she also reveals that the centre was getting difficulties in obtaining financial support to the micro-level dialogue, whereas the state and municipality may offer financial support to social projects.

While the Islamic-Christian Study Centre has reinvented itself along the way, other initiatives are characterised by being issue specific. Together with the decentralised and fragmented structure the issue specificity makes each initiative fragile vis-à-vis economical resources and thereto often time limited. The Jewish-Christian-Muslim Forum was a response to the Copenhagen shootings in February 2015 that involved an attack on the Danish synagogue. ${ }^{50}$ The Christian-Muslim Dialogue Forum was a response to the Danish Prophet Mohammed cartoon controversy. ${ }^{51}$ And, when the Contact Group for Muslims and Christian Leaders initiated the Danish-Arab Interfaith Dialogue programme, it utilised the funders' focus on democratic development in the region after the Arab uprisings, receiving funding from the Danish-Arab Partnership Programme (DAPP). ${ }^{52}$ Having organised the four planned conferences, the Contact Group was dissolved. ${ }^{53}$

To sum up, what appears important for the governance of religious diversity through interreligious dialogue is not, for example, the new law on religious communities, but how the Church of Denmark and civil society as a whole

49 Baig, Rasmussen, and Iversen, Human First - To Be Witnesses to Each Other's Life; Rasmussen, Diapraksis Og Dialog Mellem Kristne Og Muslimer.

50 The attack, sometimes called the Copenhagen shootings, took place in February 2015 when a radicalized young Muslim man killed a film director and a guard of the Synagogue in Copenhagen.

51 Christensen/Vestergaard, Rapport Fra Konference for Kristne Og Muslimske. For an analysis of the controversy, see Henkel, Fundamentally Danish? The Muhammad Cartoon Crisis as Transitional Drama.

52 Organised interreligious dialogue between Arab and Danish religious leaders, activists, and grassroots organisations became part of Danish development and foreign politics with the launch of the programme The Arab Initiative in 2003, now The Danish-Arab Partnership Programme (DAPP).

53 According to the Secretary General of the National Council of Churches, Mads Christoffersen, the council still have a close relationship to the Muslim representatives who were members although they now meet in other contexts (personal email correspondence 24.03.2020). 
draw on the entanglement of decentralised pragmatism, secularism and peoplehood supported by neoliberal politics. In the following I argue that this entanglement reproduces particular secularised subjectivities that are offered across diverse forms of interreligious dialogue. Whereas other dialogue forms like peace prayers, cross-cultural dinners at the congregational level, etc., are also common forms, I will in the following focus on leaders' and people-topeople's dialogue.

\section{4 Speaking for or on Behalf of Religious Communities?}

Whereas religious leaders often play a key role in interreligious dialogue, this role varies according to the national and religious context. ${ }^{54}$ In a Danish context, leaders' dialogue is also a common feature of interreligious dialogue. Recurrent instigators and participants are leaders - primarily clerics but also lay people - from within the Church of Denmark. However, without an independent, national representation within the Church of Denmark, for instance a church council or synod, it raises the question of what leaders from within the church represent when participating in interreligious dialogue. If they do not talk on behalf of the church as one entity, for whom do they then speak for or on behalf of?

One of the church bodies that has supported leaders' dialogue is the already mentioned Committee for Church and Encounter with other Religions of the Evangelical Lutheran Church in Denmark (Folkekirke og Religionsmøde), which has the aim to strengthen relations between the Church of Denmark and other religions and support successful and fruitful interreligious encounters. Symptomatically only nine out of ten dioceses are partners, which emphasises that any umbrella organisation within the Church of Denmark depends on voluntary membership. ${ }^{55}$ Since 2006 , the Committee has supported the Christian-Muslim Dialogue Forum, which is a forum for Christian and Muslims leaders in Denmark. The participating leaders are not only representing a particular parish or mosque but also include independent spokespersons or opinion makers. Another similar initiative focusing on religious leaders' dialogue is the Contact Group for Muslims and Christian Leaders with

54 See for example Haddad/Fischbach, Interfaith Dialogue in Lebanon; Hansen, Christian-Muslim Relations in Egypt: Politics, Society and Interfaith Encounters; Liebmann, Interfaith Dialogue in Christian Norway.

55 Religionsmoede.dk. 
representatives from the National Council of Churches (Danske Kirkers Råd) ${ }^{56}$ and from the Muslim CouncilofDenmark. This contact group was established at a national level in 2008, and in 2011 it introduced a row of four conferences under the Danish-Arab Interfaith Dialogue programme initiating a transnational interreligious dialogue between Muslims and Christians in Denmark and in Arab countries. ${ }^{57}$

A third example is The Jewish-Christian-Muslim Forum that was established in 2015 on the initiative of Copenhagen's bishop, Peter Skov-Jakobsen. As a response to the Copenhagen shootings, the forum reached out for dialogue between Jewish, Christian and Muslim leaders. In the year that followed, this led to public appearances, typically in auspices of the Church of Denmark, where leaders representing the three religions took up common issues of concern for all three religions. Despite a shared focus on leaders' dialogue, the three examples differ in regard to the role of the leader. In order to capture the vicarious and ambivalent position of the Church of Denmark, I will point at some of the challenges that each of these initiatives have faced.

When announcing The Jewish-Christian-Muslim Forum, members of the right wing of the Church of Denmark criticised the bishop for promoting himself as a religious leader and for claiming to talk on behalf of the church and thus to usurp the power that was not his. ${ }^{58}$ Skov-Jakobsen, on the other hand, rejected the accusations and emphasised that Copenhagen's bishops always had had "an interest in the wellbeing of Copenhagen's citizens" while underlining the purpose of fighting religiously motivated hate crimes and protecting the freedom of religion, including the minorities'. ${ }^{59}$ While downplaying his own role as religious leader and emphasising the wellbeing of the citizens, he spoke into the decentralised structure of the Church legitimating his participation by indirectly referring to the local church councils' high degree of independence. One of the Muslim leaders who was part of the forum at the time was the hospital imam, Naveed Baig. In an interview, he emphasised that he was not representing a particular Muslim community but does what he does as Naveed. He argued that Muslims instead need many representatives, "who are not necessarily representatives for something, but just Muslims, - or just human beings. ${ }^{\prime 60}$ Like the bishop he downplayed his role as representative.

$56 \quad$ www.danskekirkersraad.dk.

57 Christoffersen, Hoxbroe/Vinding, From a Common Word to Committed Partnership.

$5^{8}$ enevoldsen@k.dk, Bør Biskop Reprcesentere Folkekirken i Tvœrreligiøst Forum?

59 Skov-Jakobsen, Samtalen Mellem Religioner Er Vigtig.

6o Personal interview with Naveed Baig, April 2017. 
In the Christian-Muslim Dialogue Forum the question of representation appears when discussing content of the dialogue. The Christian participants, dominated by theologians, have wanted to discuss theology, while the Muslim participants have wanted to discuss issues related to challenges of belonging to a religious minority in a Danish context. Whereas both groups are concerned with challenges that threaten the internal order of their religious communities, the Christian and Muslim participants position themselves differently. The Christian theologian emphasises his/her own professional role representing the church, not necessarily as religious leader, but as a kind of (theological) expert. The Muslim participants on the other hand raise questions of general concern among Muslims in Denmark taking the position of talking for the deprived minority.

Compared to the first two examples, the Contact Group for Muslims and Christian Leaders to a much higher degree - intentionally or not - positioned the religious leaders as representatives of religious communities. During a conference held in the Common Hall (Fcellessalen), which is one of the meeting rooms in the Danish Parliament, Christiansborg, one of the invited religious scholars requested and was given the floor. Despite not being announced in the programme, he insisted speaking, because no one else had spoken on behalf of his Shia Muslim community. This kind of representation was not necessarily embraced by the Danish organisers, but the close cooperation with the Lebanese organisation and NG O: Forum for Development, Culture and Dialogue, seemed to strengthen the role of religious leaders as representatives. ${ }^{61}$

The three examples indicate that the role of the religious leader in leaders' dialogue is ambiguous. While they are representatives, what they represent differs. And what the particular Danish context seems to suggest is that religious leaders are leaders due to their professional role within e.g. the church, but not due to a particular religious authority that they possess. They do not speak for the people, but may speak on behalf of or, by vicariously performing a Christianity, on behalf of the people. Articulating a particular 'Danish way' is not alien to organisers. Thus, one organiser argued that he initially admired the Norwegian model of offering equal rights for all religions. However, he eventually discarded it, "because it's really very unlike the Danish way, it's ufolkeligt (not in accordance with the people or peoplehood), in a way, since the State becomes too big." 62

61 Galal/Hvenegård-Lassen, Organised Cultural Encounters. Practices of Transformation, p. 113 .

62 Personal interview with organiser, May 2017. 
Dabelsteen argues that despite competing secularisms between those who defend the unique status of the church and those who want to liberalise by assigning equal status to all religions, they "share an understanding of the Church of Denmark as a public good for the wider society and not just for church members." ${ }^{3}$ In other words, the role of the church is to make the nation stick together on behalf of the state. This has not become less important in a secular Europe with new religious diversity, as Joppke argues: "if the state wants to associate itself with religion, it can do so only by transforming religion into culture." ${ }^{4}$ In other words, the church - like the organiser mentioned above and the state perceive the church as a promoter of folkelighed - peoplehood by declaring religion 'culture'.65 In this way, working with religious difference is not about changing unequal relations, but about creating a collective Danish 'we', regardless of religious differences.

When perceiving the Church of Denmark as "the primary religious site for affirmation of Danish peoplehood," it indirectly makes it difficult for other religious communities to obtain the same symbolic recognition of citizenship. ${ }^{66}$ Whereas Baig has obviously embraced 'the Danish way' and maybe therefore has been a popular dialogue partner for years, not all Muslims appear equally good - according to the majority - at observing the right balance between representation and subjectivity. When talking with a pastor from the Church of Denmark, who has been active in organising and supporting interreligious dialogue, he argued that Ahmadiyya Muslims were not relevant to include in interreligious dialogue. The reason for rejecting them appeared a bit blurred, but he seemed to argue that they were not relevant because other Muslims considered them not truly Muslims. Thus, they could in other words not be representatives of Muslims. Again, it is stressed that dialogue partners are expected to simultaneously perform representation and subjectivity. The idea of the Church of Denmark as legitimately embodying the Danish people seems to be transmitted to the choice of Muslim dialogue partners. The result is a reproduction of a generalised Muslim 'other' vis-à-vis a generalised Danish 'we'. Thus, whereas leaders' dialogue is generally legitimised by leaders' ability to influence their followers, the dialogue initiated or supported by Christian leaders rather holds performative and affective processes constituting togetherness. ${ }^{67}$

63 Dabelsteen, Same Rights for Everybody?, p. 44.

64 Joppke, Culturalizing Religion in Western Europe, p. 236.

65 Joppke, Culturalizing Religion in Western Europe, p. 238.

66 Dabelsteen, Same Rights for Everybody?, p. 42.

67 Platt/Medway, Sometimes ..., p. 11. 
A kind of togetherness that draws on strong ideas of a particular Danish, culturalised Christianity legitimised by the 'people'.

\section{$5 \quad$ Portraying Yourself}

A paradoxical consequence of the Church of Denmark's dominant position in organising religion - and interreligious dialogue - is a decentralised, varied, partly fragmented, but also inter-connected interreligious dialogue field. The decentralised and culturalised Danish Church together with a rich civil society as a whole give room for various NGOs to engage in interreligious dialogue. Compared to the Church bodies mentioned above, some NGOs place themselves more explicitly within a discussion about equality between religions. The president of the Faith in Harmony Forum (Tro i Harmoni) motivates her engagement in interreligious work by referring to the demonization of religious Others and the struggle for creating a space for talking about faith. The Faith in Harmony Forum is a Danish grassroots group based in Copenhagen. With Christian, Jewish, Muslim, Sikh and Buddhist members, the Faith in Harmony Forum is an example of a multilateral interfaith group, established in 2012. It differs from most other initiatives by its multifaith board and a president who, despite being Christian, does not have her religious roots in the Church of Denmark. Every year in February, it organises interreligious activities in connection with the FN World Interfaith Harmony Week. Being a very small organisation, the Forum brings religion into the public sphere by allying with other religious and non-religious organisations, the Church of Denmark and municipalities. Paradoxically, however, rather than lobbying for equality, the Forum in its activities appears to embrace the same kind of culturalised religiousity of Danish peoplehood as the Church of Denmark. The president emphasises about her position:

You have an experience of connecting and becoming recognised as well as recognising the other, or recognising yourself in the other. And, this is indeed what makes it so great when it comes about. Because you bypass all kinds of intellectualism and end up just being humans together. ${ }^{68}$

By rejecting intellectualism and emphasising "just being humans together", the president draws on ideas for which Grundtvig is commonly credited and

68 Personal interview with the president, June 2017. 
often repeated by other organisers of interreligious dialogue. ${ }^{69}$ The idea of a universal human being that comes before and stands beside one's particular faith reflects Grundtvig's understanding of human beings as created in God's image. ${ }^{70}$ Grundtvig accused university theology for having developed into an "exegetic pope rule" as a centralised, theological authority that claimed monopoly of interpreting the Bible. Instead, he argued that the church is not an institution, but consists of living human people - a congregation -, who believe in the truth of Christianity. He wanted to give more authority to local communities rather than to the church as a centralised church. The church as a state church should just provide the space for the congregations. Thus, when the NGO president talks about "bypassing all kinds of intellectualism", it resonates with Grundtvig's rejection of the university theology and the emphasis on togetherness.

This focus on being humans together is translated into an interest in the believer's relation to her own faith. During activities organised by the Interfaith Forum, but also by organisers such as Danmission Ikon that organises training in interreligious dialogue preparing participants to initiate and organise interreligious dialogue, participants are continually encouraged to perform witnessing in specific ways. ${ }^{71}$ Participants are asked to tell their individual story and to find their "inner voice". In this way, emphasis is on "the interior of the human" and "the experience of faith" leading back to not only Grundtvig but also Pietism's critique of the church. ${ }^{72}$ Thus, in this version the push of interreligious dialogue towards transformation targets the individual subject. By being true to your believing self, you bear witness (for Christianity) converging subjectivity and representation.

The fragmented and decentralised nature of the Danish interreligious dialogue field is, as argued, embedded in historically constituted ideas about the church as embodying the people, a culturalised and secularised version of Lutheran Protestantism with focus on peoplehood, ideas of togetherness and individualism. In other words, not only leaders' dialogue but also people-to-people's

69 Baig, Rasmussen/Iversen, Human First - To Be Witnesses to Each Other's Life; Jørgensen, Mission, Dialog Og Omvendelse.

70 Møller, Grundtvigs Død.

71 Galal/Hvenegård-Lassen, Organised Cultural Encounters. Practices of Transformation; Galal, Interfaith Dialogue - a Quest for Authenticity.

72 Buchardt, Church, Religion and Morality; Thyssen, Grundtvig Og Spener. 
dialogue appear to reproduce a focus on the individual believer's inner faith, thereby disregarding the asymmetrical power relation between majority and minority exposed in public discourses on for instance Islam and Muslims. The result is a paradoxical construction of firsts and otherings that remain asymmetrical. No discussion seems to take place contesting the strong focus on the individual, regardless that this focus may deviate from other interreligious dialogue models, for instance models that are more preoccupied with the repairing of the group or community and their values than the individual. ${ }^{73}$ Taking point of departure in the majority's sense of order, the interreligious dialogue reproduces the majority religion's position and perspective on religion and dialogue. I am not arguing that other more positive outcomes of interreligious dialogue in a Danish context do not exist - such as creating friendship, network, and knowledge across differences - but here I have focused on the social-cultural and historical context and its impact on the dialogue.

Within the last few years, new initiatives like The New Voices and Bigoted Diplomates have appeared. Without including Christians but addressing dialogue between Jews and Muslims, they may be alternatives to the interreligious dialogue initiatives dominated by the Church of Denmark, potentially challenging the ambiguous balancing of representation and subjectivity explored in this paper.

\section{Biography}

Lise Paulsen Galal is an Associate Professor in Cultural Encounters at Roskilde University, Denmark. Her research interests include interdisciplinary approaches to minority-majority relations, practices and management of religious diversity, and transnational belonging among migrants. Trained as an anthropologist she has conducted fieldwork in Egypt, the UK and Denmark. As the leader of the research project The Organised Cultural Encounters (funded by the Independent Research Fund Denmark), she has examined organised interreligious dialogue activities in a Danish context. Galal has published widely on cultural and religious diversity including the books Organised Cultural Encounters. Practices of Transformation (co-authored with Hvenegård-Lassen and published by Palgrave Macmillan, 2020) and Cultural Encounters as Intervention Practices (co-edited with Christiansen and Hvenegård-Lassen, and published by Routledge, 2019). 


\section{Bibliography}

Agrawal, Sandeep/Barratt, Caitlin: Does Proximity Matter in Promoting Interfaith Dialogue?, in: Journal of International Migration and Integration 15 (3/2014), pp. $567-587$.

Andreassen, Rikke/Ahmed-Andresen, Uzma: I Can Never Be Normal: A Conversation about Race, Daily Life Practices, Food and Power, in: European Journal of Women's Studies 21 (1/2014), pp. 25-42.

Baig, Naveed/Rasmussen, Lissi/Iversen, Hans Raun: Human First - To Be Witnesses to Each Other's Life: Twenty-One Years of Struggle for Equal Human Dignity, in: Exploring the Multitude of Muslims in Europe. Leiden, Boston, MA: Brill, 2018, pp. $155^{-171 .}$

Borup, Jern: Hvor mange buddhister lever i Danmark? Religion.dk, https://www.religion.dk/hvor-mange-buddhister-er-der-i-danmark (date of last access: 17.07.2019).

Buchardt, Mette: Church, Religion and Morality, in: Bloomsbury Histories of Education: The Age of Enlightenment, ed. by Gary Mcculloch. London: Bloomsbury Academic, forthcoming.

Buchardt, Mette: Cultural Protestantism and Nordic Religious Education: An Incision in the Historical Layers behind the Nordic Welfare State Model, in: Nordidactica: Journal of Humanities and Social Science Education (2/2015), pp. 131-165.

Christensen, Kåre Schelde/Vestergaard, Ida Louise: Rapport Fra Konference for Kristne Og Muslimske Ledere i Danmark 2016 [Report from a Conference for Christian and Muslim Leaders in Denmark 2016]. Copenhagen: Stiftssamarbejdet Folkekirke og Religionsmøde, 2016.

Christiansen, Lene Bull/Galal, Lise/Hvenegård-Lassen, Kirsten (eds.): Organised Cultural Encounters: Interculturality and Transformative Practices. Special Issue, in: Journal of Intercultural Studies 38 (6/2017), pp. 599-6o5.

Christoffersen, Mads/Hoxbroe, Stine/Vinding/Valdemar, Niels (eds.): From a Common Word to Committed Partnership: Danish-Arab Interfaith Dialogue 2012-16. Frederiksberg: Secret Chamber Press, 2018.

Connolly, Paul: What Now for the Contact Hypothesis? Towards a New Research Agenda, in: Race, Ethnicity and Education 3 (2/200o), pp. 169-193.

Dabelsteen, Hans B.: Unity Through Separation: On the Construction of Danish Secularism [Om Konstruktionen Af Dansk Sekularisme]. Department of Political Science, University of Copenhagen, 2015.

Dabelsteen, Hans Bruun: Same Rights for Everybody? On Secularism, Modest Establishment and Same-Sex Marriage, in: Ethnicities 15 (1/2015), pp. 28-52.

www.danskekirkersraad.dk/. National Council of Churches in Denmark, https://www. danskekirkersraad.dk/ (date of last access: 23.07.2019). 
Davie, Grace: Religion in Europe in the 21 St Century: The Factors to Take into Account, in: European Journal of Sociology/Archives Européennes de Sociologie 47 (2/2006), pp. 271-296.

Den katolske Kirke i Danmark. Bispedømmet København. Statistik, https://www.katolsk.dk/bispedmmet/bispekontoret/statistik/ (date of last access: 17.07.2019).

Dick, Eva/Nagel, Alexander-Kenneth: Local Interfaith Networks in Urban Integration Politics: Religious Communities between Innovation and Cooptation, in: Victoria Hegner/Peter Jan Margry (eds.): Spiritualizing the City. London: Routledge, 2016, pp. 39-57.

Duemmler, Kerstin/Nagel, Alexander-Kenneth: Governing Religious Diversity: Top-down and Bottom-up Initiatives in Germany and Switzerland, in: Integrative Psychological and Behavioral Science 47 (2/2013), pp. 265-283.

enevoldsen@k.dk. Bør Biskop Reprœesentere Folkekirken i Tvœrreligiøst Forum? [Should theBishop Represent Folkekirken in an Interreligious Forum?], in:Kristeligt Dagblad. 07/2015, https://www.kristeligt-dagblad.dk/kirke-tro/skal-biskop-repraesenterefolkekirken-i-tvaerreligioest-forum (date of last access: 02.09.2020).

Fibiger, Marianne Qvortrup: Hvor mange hinduer bor i Danmark? Religion.dk, https://www.religion.dk/hvor-mange-hinduer-bor-i-danmark (date of last access: 17.07.2019).

Fortier, Anne-Marie: Proximity by Design? Affective Citizenship and the Management of Unease, in: Citizenship Studies 14 (1/2010), pp. 17-30.

Furseth, Inger/Ahlin, Lars/Ketola, Kimmo/Leis-Peters, Annette/Repstad, Pål/ Sigurvinsson, Bjarni/Randver, Urstad/Sivert Skålvoll: Faith and Worldview Communities and Their Leaders - Inward or Outward Looking?, in: Inger Furseth (ed.): Religious Complexity in the Public Sphere: Comparing Nordic Countries. London: Palgrave Macmillan, 2017, pp. 251-289.

Galal, Lise Paulsen: Dialogens Arrangement: Når muslimer og kristne mødes [The organisation of dialogue: When Muslims and Christians meet], in: Tidsskrift for Islamforskning 9 (2/2015), pp. 48-67.

Galal, Lise Paulsen: Interfaith Dialogue - a Quest for Authenticity, in: Religious Matters in an Entangled World (blog), o7/2018, https://www.religiousmatters.nl/buildingsimages-and-objects/article/blog-interfaith-dialogue-a-quest-for-authenticity/ (date of last access: 02.09.2020).

Galal, Lise Paulsen: Making Space for Faith. Interfaith Initiatives in Denmark, in: John Fahy/Jan-Jonathan Bock (eds.): The Interfaith Movement: Mobilising Religious Diversity in the 21st Century. London: Routledge, 2019.

Galal, Lise Paulsen/Hvenegård-Lassen, Kirsten: Organised Cultural Encounters. Global Diversities. London: Palgrave Macmillan, $202 \mathrm{O}$. 
Galal, Lise Paulsen/Liebmann, Louise L./Nordin, Magdalena: Routes and Relations in Scandinavian Interfaith Forums: Governance of Religious Diversity by States, Majority Churches, and Dedicated Individual Actors, in: Social Compass 65 (3/2018), pp. 329-345.

Giordan, Giuseppe/Lynch, Andrew P.: Interreligious Dialogue: From Religion to Geopolitics, in: Giuseppe Giordan/Andrew P. Lynch (eds.): Interreligious Dialogue: From Religion to Geopolitics. Leiden/Boston, MA: Brill, 2019, pp. 1-9.

Griera, Mar: Public Policies, Interfaith Associations and Religious Minorities: A New Policy Paradigm? Evidence from the Case of Barcelona, in: Social Compass 59 (4/2012), pp. 570-587.

Griera, Mar/Nagel, Alexander-Kenneth: Interreligious Relations and Governance of Religion in Europe: Introduction, in: Social Compass 65 (3/2018), pp. 301-311.

Grung, Anne Hege: Interreligious Dialogue: Moving between Compartmentalization and Complexity, in: Approaching Religion 1 (1/2011), pp. 25-32.

Haddad, Yvonne Yazbeck/Fischbach, Rahel: Interfaith Dialogue in Lebanon: Between a Power Balancing Act and Theological Encounters, in: Islam and Christian - Muslim Relations 26 (4/2015), pp. 423-442.

Hansen, Henrik L.: Christian-Muslim Relations in Egypt: Politics, Society and Interfaith Encounters. London: I.B. Tauris, 2015.

Hansen, Janna/Herbert, David: Life in the Spotlight: Danish Muslims, Dual Identities, and Living with a Hostile Media, in: Knud Lundby (ed.): Contesting Religion. Berlin/ Boston, MA: De Gruyter 2018, pp. 205-222.

Helqvist, Iben: Muslimske Interesseorganisationers Samarbejde Med Integrationsministeriet, in: Tidsskrift for Islamforskning 4 (2/2010), pp. 104-116.

Henkel, Heiko: Fundamentally Danish? The Muhammad Cartoon Crisis as Transitional Drama, in: Human Architecture 8 (2/2010), pp. 67-81.

Jacobsen, Brian Arly: Denmark, in: Yearbook of Muslims in Europe 9 (2016), pp. 206-218. Joppke, Christian: Culturalizing Religion in Western Europe: Patterns and Puzzles, in: Social Compass 65 (2/2018), pp. 234-246.

Joediskinfo.dk, https://joediskinfo.dk/artikler/danske-joeder (date of last access: 22.08.2020).

Jørgensen, Knud: Det Nye Areopagos: Fremtidens Kristendom i Religionsmødets Perspektiv, in: Norsk Tidsskrift for Misjonsvitenskap (2/2012), pp. 67-88.

Jørgensen, Theodor: Mission, Dialog Og Omvendelse - et Spørgsmål Om Engagement, Respekt Og Tillid [Mission, Dialogue and Conversion - a Question of Engagement, Respect and Thrust], 2000, http://www.islamstudie.dk/dialog_dialog.theo.htm.

Korsgaard, Ove: Grundtvigs Bidrag Til Opbygning Af En Ny Symbolsk Orden [Grundtvig's Contribution to the Building of a New Symbolic Order] in: Ove Korsgaard/Michael 
Schelde (eds.): Samfundsbyggeren [The Society Builder]. Copenhagen: Forlaget Anis, 2013, pp. 89-106.

Kirkeministeriet. Folkekirkens medlemstal, http://www.km.dk/folkekirken/kirkestatistik/folkekirkens-medlemstal/ (date of last access: 26.03.2020).

Kristensen, Nikolaj Rodkjær: Hvor Mange Muslimer Er Der i Danmark [How Many Muslims Live in Denmark?], in: Tjek Det - Leveret Af Mandagmorgen. 04/2020, https://www.mm.dk/tjekdet/artikel/hvor-mange-muslimer-er-der-i-danmark (date of last access: 02.09.2020).

Liebmann, Louise Lund: Interfaith Dialogue in Christian Norway: Enactment of Inclusive Religiosity as Civilized Behavior, in: Journal of Religion in Europe 10 (3/2017), pp. 301-327.

Martikainen, Tuomas: Multilevel and Pluricentric Network Governance of Religion, in: François Gauthier/Tuomas Martikainen (eds.): Religion in the Neoliberal Age. New York, NY: Routledge, 2016, pp. 141-154.

Matejskova, Tatiana/Leitner, Helga: Urban Encounters with Difference: The Contact Hypothesis and Immigrant Integration Projects in Eastern Berlin, in: Social \& Cultural Geography 12 (7/2011), pp. 717-741.

Mayblin, Lucy/Valentine, Gill/Andersson, Johan: In the Contact Zone: Engineering Meaningful Encounters across Difference through an Interfaith Project, in: The Geographical Journal 182 (2/2016), pp. 213-222.

Mogensen, Mogens: Mellem Mission Og Dialog [Between Mission and Dialogue], in: Berit Schelde Christensen/Viggo Mortensen/Lars Buch Viftrup (eds): Karma, Koran Og Kirke. Religiøs Mangfoldighed Som En Folkekirkelig Udfordring [Karma, Koran and Church. Diversity as a Challenge for the People's Church]. Århus: Forlaget Univers, 2007, pp. 111-118.

Mogensen, Mogens/Christensen, Kåre Schelde: Rapport Fra: Tcenketank Vedr. Udredning Og Anbefalinger Om Religionsmødekvalifikationer i Fremtidens Uddannelsesforløb for Præster i Folkekirken [Report from: Think Tank Regarding Investigation of and Recommendations for the Future Education of Pastors in the People's Church in Interfaith Encounters]. Frederiksberg: Stiftssamarbejdet Folkekirke og Religionsmøde, 2015, https://religionsmoede.dk/_Resources/ Persistent/e/e/4/2/ee4255fefb7e7ece6co89e43cc319ae4f98b6364/X_rapport-fra-TT. pdf (date of last access: 02.09.2020).

Møller, Jes Fabricius: Grundtvigs Død [The Death of Grundtvig]. Aarhus: Aarhus Universitetsforlag, 2019.

Nielsen, Marie Vejrup: Appealing to the State Church Identity in Processes of Change, in: Journal of Church and State 58 (2/2014), pp. 213-233.

Nielsen, Marie Vejrup/Kühle, Lene: Religion and State in Denmark: Exception among Exceptions?, in: Nordic Journal of Religion and Society 24 (2/2011), pp. 173-188. 
Norris, Pippa/Inglehart, Ronald: Sacred and Secular: Religion and Politics Worldwide. Cambridge University Press, 2011.

Petersen, Laura Bjørg Serup: Intercultural Encounters in the Danish Church, in: Nordics. Info, 29 03/2019, http://nordics.info/show/artikel/intercultural-encounters-in-thedanish-church/ (date of last access: 02.09.2020).

Platt, Louise C./Medway, Dominic: Sometimes ... Sometimes ... Sometimes ... Witnessing Urban Placemaking from the Immanence of 'the Middle', in: Space and Culture (January 2020).

Plan of action for Folkekirke og Religionsmøde until 2020. https://religionsmoede. $\mathrm{dk} /$ Resources/Persistent/8/7/c/o/87co52711884e89861d55c25302332d581c96d7e/ Handlingsplan\%2otil\%2O2O2O\%2C\%2ovedtaget\%2O30.05.2017.pdf (date of last access: 09.08.2019).

Pratt, Mary Louise: Arts of the Contact Zone, in: Profession (1991), pp. 33-40.

Rasmussen, Lissi (ed.): Bridges Instead of Walls: Christian-Muslim Interaction in Denmark, Indonesia and Nigeria. Minneapolis, MN: Lutheran University Press, 2007.

Rasmussen, Lissi: Diapraksis Og Dialog Mellem Kristne Og Muslimer: I Lyset Af Den Afrikanske Erfaring [Diapraxis and Dialogue between Christians and Muslims: The African Experience]. Arhus: Aarhus University, 1997.

Religionsmoede.dk, https://religionsmoede.dk/ (date of last access: 10.05.2019).

Retsinformation. Law no 1533, 19/12/2017, https:/www.retsinformation.dk/Forms/ ro710.aspx?id=196402 (date of last access: 25.07.2019).

Rehman, Uzma: Konfliktløsning Og Fred: Vestlige Og Muslimske Tilgange [Conflict Resolution and Peace: Western and Muslim Approaches], in: Lene Sjørup (ed.): Vendepunkter: Religion Mellem Konflikt Og Forsoning [Turning Points: Religion between Conflict and Reconciliation]. Odense: University Press of Southern Denmark, 2007, pp. 171-182.

Skov-Jakobsen, Peter: Samtalen Mellem Religioner Er Vigtig [The Dialogue between Reigions Is Important], in: Kristeligt Dagblad. 07/2015, https://www.kristeligtdagblad.dk/kronik/samtalen-mellem-religioner (date of last access: 02.09.2020).

Studiecenter, https://www.facebook.com/groups/studiecenter/about/ (date of last access: 22.08.2020).

Thyssen, A. Pontoppidan: Grundtvig Og Spener. Især Til Belysning Af Den Pietistiske Grundtvig [Grundtvig and Spener. In Particular Concerning the Pietistic Grundtvig], in: Grundtvig-Studier 20 (1/1967), pp. 9-5o.

Valentine, Gill: Living with Difference: Reflections on Geographies of Encounter, in: Progress in Human Geography 32 (3/2008), pp. 323-337.

Vejledning $i$ religionsmøde, https://religionsmoede.dk/materialer/vejledning-ogbaggrund/vejledning-i-religionsmoede (date of last access: 09.09.2019). 
Vinding, Niels Valdemar/Christoffersen, Lisbet: Danish Regulation of Religion, State of Affairs and Qualitative Reflections. A Report on 20 Qualitative Elite Interviews, 2012, https://teol.ku.dk/ceit/religare/Danish_Report_Final_2012.pdf/ (date of last access: 20.09.2020).

Wilson, Helen F: On Geography and Encounter: Bodies, Borders and Difference, in: Progress in Human Geography 41 (4/2017), pp. 451-471.

Wolf, Alain: Intercultural Identity and Inter-Religious Dialogue: A Holy Place to Be?, in: Language and Intercultural Communication 12 (1/2012), pp. 37-55. 